\title{
Users' Perception of University Library Resources and Services in South East Zone of Nigeria
}

\author{
Obiozor-Ekeze Roseline Nkechi \\ Nnamdi Azikiwe University Library, Awka, Nigeria \\ Email: roseobiozor70@gmail.com
}

Received 24 October 2014; accepted 24 March 2015; published 27 March 2015

Copyright (C) 2015 by author and Scientific Research Publishing Inc.

This work is licensed under the Creative Commons Attribution International License (CC BY).

http://creativecommons.org/licenses/by/4.0/

c) (7) Open Access

\begin{abstract}
This study seeks to determine how users of the university libraries perceive the services rendered to them. Department of Mechanical Engineering was chosen as the population of this study. It is heavily populated with students seeking for information. 600 copies of questionnaire were made, only 450 copies were returned, well-filled, that is $75 \%$ of the questionnaire. Results were gathered and findings were made. The result showed that University Libraries are underfunded, they lack qualified personnel and also the university libraries do not have a general standard that guild them to access if actually users of the libraries are satisfied with the library or not.
\end{abstract}

\section{Keywords}

University Libraries, Information Services, Department of Mechanical Engineering, Students, Standards, South East of Nigeria

\section{Introduction}

There are about ten (10) universities in the South East of Nigeria and each of them has not less than eight (8) faculties. South East Zone of Nigeria is heavily populated with students aiming to acquire one specialization or the other. It is really an information seeking zone in Nigeria. The universities have libraries that support them to achieve their objectives: be supportive to teaching, learning and research, be supportive to the mission and goals of their institutions. Gyure (2008) stated that university library is "the heart of an academic institution for accumulating knowledge. Some years back, the university libraries were acquiring materials on printed forms only, but presently, it is a different situation. The application of new technologies have changed and reshaped the needs, perception and expectation of users. Library's users expect more from the libraries. Since the advent of 
internet in libraries, the university libraries satisfy their users more. Internet resources have helped the collections of the university libraries to be rich. Users can access the online public access catalogue (OPACS) for more information unlike when it was only the libraries traditional catalogues. In a research carried out by Baikady \& Mudhot (2011) on web learning resources in a medical college in India, they discovered that staff and students prefer using web resources than going to the library to use books or journal, which they are not sure are in the library. They use of OPAC is one of the greatest things that have happened to the university libraries. It provides current information resources to the users.

University libraries provide many services to their users: Collection development, reference services, organization of knowledge, users' education etc. These services are being carried out by the Librarians. Murphy (2000), Beverly, Both and Bath (2003) reported the unique roles played by the university libraries through their librarians, as information professionals, they gather, organize and coordinate access to the best available information resources for library users. During collection development, the librarians liaise with the faculty representatives so as to acquire the necessary materials. For reference services, the users of the libraries are provided with quality information through the librarians. Bureau Adelabu (2004) calls these librarians "information providers". He reported that librarians also provide online chart and email for the users. University library organizes orientation courses for the newly admitted students as information literacy. It takes the form of a lecture, guided tours and formal bibliographic instruction. Glynn and Wu (2003) pointed out that the university libraries offer training services to the students and researchers in finding information effectively on the web for academic purposes.

What librarians are thinking of now is how to provide quality services to their clienteles. In developed countries, university libraries have standards and policy that guide them to evaluate services rendered to users of libraries. Cullen and Calvert (1993) observe that several ways could be adopted to evaluate library resources and services. He noted that input evaluation based on finances, staff resources and collection and output evaluation based on process efficiency measures are indices of how services are provided by the library.

In South East Nigeria, university libraries have a lot of problems hindering them from satisfying their users especially in science and technology. However, are studies on individual universities from other geopolitical zone on users' satisfaction, but the researcher carried out this study collectively on user's perception of libraries services and resources under Mechanical Engineering Departments, in South East Universities in Nigeria.

\section{Purpose of Studies}

The purpose is to find out if staff and students of Mechanical Engineering using the university libraries are satisfied with the services and resources provided in the university libraries. Specifically to know if

1) The university library provides current books and journals for the department.

2) Know if internet service provided in the library is functional.

3) Know if there is a science based librarian in the university library that assist in providing services for the department.

\section{Research Questions}

1) What is the state of collection development for your department in your university library?

2) Is the internet service provided functional?

3) How capable are the librarians in your university libraries in handling science and technology matters?

\section{Methodology}

This study adopted descriptive survey design. The area of study is the university libraries in South Eastern Zone of Nigeria. The population of study is only registered staff and 300 level students from departments of Mechanical Engineering. This department was chosen because it is a common department in all the chosen universities and also heavily populated with male students. Their ages are between 19 and 24 years. The staffs chosen were mainly younger lecturers that have not worked for 5 years.

\section{Instrument}

A questionnaire on "Users Perceptions on University Library Resources and Services" was constructed for data collection. 600 copies of the questionnaire were duplicated and distributed with research assistances. They were 
collected after two (2) weeks. 450 are the respondents. Their copies of questionnaires were well completed were returned. That is $75 \%$ of the questionnaires.

\section{Findings}

It was gathered that $60 \%$ of the respondents reported that the university libraries do not have current materials on Science and Technology. Current foreign journals are not in the libraries and the local journals are not continuous. The University libraries are under funded, especially the state and private university libraries. Federal university libraries have more advantages over the state and private university libraries. Agboola (2000) reported that for about five (5) decades federal and state governments have been the sole financers of libraries in Nigeria. In 1993, the National Universities Commission (NUC) legislated that $10 \%$ of the approved recurrent budget for Nigeria Federal Universities be set aside for library development. But the goodwill was withdrawn in 2001. The government is not actually encouraging the growth of libraries in Nigeria. Under funding affects the growth of libraries greatly. In collection development, underfunding affects the acquisition of materials, especially in Engineering and Technology. Meaningful materials cannot be purchased without much fund. Majority of university libraries in Nigeria are not internet connected because of lack of fund. Where it exists, it may not be functional. For users satisfaction to be achieved in university libraries, both printed and electronic resources must be available for consumption.

Another hindrance is the issue of not having the qualified personnels to work in science and technology libraries. Professional librarians do not have subject specialization. Subject background helps librarians to serve better in information services. Watson (2005) explains that if a non-science librarian for instance should manage a science library, the library will be put in a tragic damage. Both the collection development and reference services will be in a mess. To support this issue on subject background in librarianship, Ifidon (2005) remarked that subject specialization helps the librarians in the area of which he specializes in, enables the librarian to have a remote access to any information within his subject area. Another point gathered, was the issue of not having standard or policies that guild them in evaluating their services.

From the look of things, each of these universities libraries is operating on its own, according to the objectives of its parent institution. National Universities Commission stipulated a standard but it is not being used by the university libraries in Nigeria.

\section{Conclusions}

University libraries in South East Zone of Nigeria should wake up to what is happening around the world. There is no way the libraries can boost of information satisfaction to their users without having information resources and qualified personals to render the services.

The printed books and journals are not sufficient for users in mechanical engineering. The universities are over populated with students and researchers lacking sufficient information. Only the privileged students use their computers to search for information or they use the Cybercafés. Federal and state governments should increase the allocations given to universities so as to support their libraries.

Another point is giving support to other staff in libraries to study librarianship. Also Librarians working in the university libraries should have subject specializations especially in sciences to support them in services and also aquire ICT trainings. Some librarians in some areas should be sent for specialist courses. When university libraries provide quality information services to researchers, quality results will be gotten. This will contribute to the economic development of Nigeria.

\section{References}

Agboola, T. (2000). Five Decades of Nigerian University Libraries. A Review of Library, 50, 280-287.

Baikady, M., \& Mudhot, M. V. (2011). Web as a Learning Resource at the Medical College Libraries in Coastal Karnataka: Perception of Faculty and Students. DESIDOC Journal of Library \& Information Technology, 31, 121-135. http://dx.doi.org/10.14429/djlit.31.2.864

Beverly, Both, \& Beverly, Bath (2003). Subject Specialist Librarians in Higher Education: A Selective Review of the Literature, with a Brief Postscript Relating to Middlesex Polytechnic Library. Learning Resources Bulletin, 4, 22-31.

Bureau Adelabu (2004). Professional Staff of Tomorrow’s Future in African University Libraries Some Poslates and Proposals. International library Review, 6, 299-308. 
Cullen, R. J., \& Calvert, P. J. (1993). Further Dimensions of Public Library Effectiveness: Report on a Parallel New Zealand Study. Library and Information Science Research, 5, 143-164.

Glynn, T., \& Wu, C. (2003). New Roles and Opportunities for Academic Library Liaisons: A Survey and Recommendations. Reference Services Review, 31, 122-128. http://dx.doi.org/10.1108/00907320310476594

Gyure, D. (2008). The Heart of the University. Winterthur Portfolio, 42, 107-132. http://dx.doi.org/10.1086/589593

Ifidon, S. E. (2005). Information Availability and the Extent of Use in Public Library. Archival and Information Science Journal, 7, 65-74.

Murphy, C. (2000). The Role of the Subject Specialist in British and American University Libraries: A Comparative Study. Libri., 29, 1-19.

Watson, E. M. (2005). Subject Knowledge in the Health Sciences Library: An Online Survey of Canadian Academic Health Sciences Librarians. Journal of Medical Library Association, 93, 459-466.

\section{Appendix}

Questionnaire

1) What is the state of collection development for mechanical engineering department?

(a) Are the materials suitable for learning and teaching?

(b) Are the materials current?

(c) How current are there in of science and technology?

(d) Does the university library subscribe to professional journals?

(e) Are there up-date?

2) Is the internet service in your university library functional?

(a) Does your university library connected to internet?

(b) Is the internet functional?

(c) Do they subscribe to academic information providers?

(d) Do they digitize information materials for researchers?

What other services do they provide?

3) Are the librarians helpful in providing services for your research work?

(a) How helpful are the librarians in handling reference materials?

(b) Are the librarians approachable? 